\title{
Jurisdiction Overview Implementation of Registration of Property Rights Transfer to Land by Grants
}

\author{
Pramudya Hutama*) \\ ${ }^{*}$ Faculty of Law, Universitas Islam Sultan Agung (UNISSULA) Semarang, E-mail: \\ pramudyah2021@gmail.com
}

\begin{abstract}
This research described and studied the freehold ownership of land transition by grant. This research is categorized as an empirical law research using the descriptive approach. This research is condusted in Kebumen Regency. There are two kinds of data that is used in this research, namely primary and secondary data. The method that is used in data collection are observation, interview, and library research based on Indonesia Law and Rules books, related documents, etc according to the topic. Data analysis using qualitative analysis by interactive model. The result of this research shows that the freehold ownership of land transition by grant in Kebumen Regency is already appropiate to the procedure in exist regulations. The freehold ownership of land transition by grant has to be registered in Kebumen Palace and National Land Office to gain certain law in the shape of title holder. Therefore the land status will be clear, it is not only about the burdens, the widht, but also the rights that in herent to it.
\end{abstract}

Keywords: Land; Registration; Grant; Document; Transfer; Rights.

\section{Introduction}

The transfer of land rights is a legal action that aims to transfer rights from one party to another. One way of transferring land rights is through grants. Grant in language means giving, while according to the term grant is giving something to someone for free, without expecting anything as a sign of affection. A grant is a gift that is made, both within the family and with other people, which is done while still alive or the grantor is still alive.

Before the birth of PP No. 24 of 1997, for those who are subject to the Civil Code, a will must be made in writing from a notary. ${ }^{1} \mathrm{~A}$ will that is not made by a notary has no legal force. Those who are subject to customary law can be carried out

\footnotetext{
${ }^{1}$ Article 1005 of the Civil Code
} 
privately, but the process at the Land Office must be made with a PPAT deed. ${ }^{2}$ After the birth of PP No. 24 of 1997, every grant of land must be done with a PPAT deed. ${ }^{3}$ The transfer of land from the owner to the beneficiary accompanied by a juridical handover (juridische levering), is a handover that must meet the legal formalities, including the fulfillment of requirements, carried out through a predetermined procedure, using documents, made by/in front of the PPAT. ${ }^{4}$

Individuals as subjects of land rights, namely every person whose identity has been registered as an Indonesian citizen domiciled in Indonesia and does not lose the right to obtain a land right, but in taking legal action in this case the land must be mature according to law. In the law it is explained that everyone can be a legal subject, but according to the provisions of the law there are legal subjects who are not perfect, meaning that legal subjects only have a will but are not able to express their will in legal actions. According to R. Subekti, they are immature people / minors, adults but unable to act (crazy), and women in marriage. ${ }^{5}$

The vast Kebumen Regency has an impact on the high transfer of land rights in various ways, one of which is through grants. This problem becomes interesting for the author to discuss it further in the thesis with the title "Juridical Overview of the Registration of Transfer of Property Rights on Land Due to Grants in Kebumen Regency".

\section{Research Methods}

This research is a normative legal research (doctrinal legal research). As with the type of normative research, the approach methods used in this research are the statute approach and the conceptual approach. ${ }^{6}$ Research sources can be divided into primary, secondary, and tertiary legal sources. The collection of legal materials is done by means of library research. ${ }^{7}$ The results of the analysis of legal materials will be interpreted using systematic and grammatical interpretation methods. ${ }^{8}$

\footnotetext{
2 Effendi Perangin, 1990, Mencegah Sengketa Tanah, cetakan ke-2, Rajawali, Jakarta, p.46

${ }^{3}$ Article 37 paragraph (1) and Article 39 of PP Number 24 of 1997 concerning Land Registration

${ }^{4}$ Abdul Kadir Muhammad, 1994, Hukum Harta Kekayaan, Issue I, Citra Aditya Bakti, Bandung, p. 55

${ }^{5}$ R. Subekti, 1994, Pokok-pokok Hukum Perdata, Internusa, Bandung p.341

6I Made Pasek Diantha, Metodologi Penelitian Hukum Normatif, Prenada Media Group, Jakarta, 2016, p. 156

${ }^{7}$ Soerjono Soekanto dan Sri Mamudji, Penelitian Hukum Normatif, Rajagrafindo Persada, Jakarta, 1985, p. 41

${ }^{8}$ Sudikno Mertokusumo, Penelitian Hukum, Liberty, Yogyakarta, 2005, p. 47
} 


\section{Result and Discussion}

The Kebumen Regency Land Office has the task of carrying out some of the duties and functions of the National Land Agency in the relevant Regency Territory. Based on the Decree of the Head of the National Land Agency of the Republic of Indonesia Number 4 of 2006 concerning the Organization and Work Procedure of the Regional Office of the National Land Agency of Central Java Province and the Land Office of Article 30, the Land Office carries out some of the duties and functions of the National Land Agency in the Regency/City.

According to Article $1666 \mathrm{BW}$, it is explained that a grant is an agreement in which the donor, in his lifetime, freely and irrevocably submits an object for the purposes of the recipient of the grant who receives the grant. The law only recognizes the giving of existing objects and between living people.

Grants are the free will of the owner of the property to donate to whomever he wants. So, the grantor acts actively to hand over the ownership of his property to the grantee without any coercion from any party.

Article 919 BW stipulates that parts that may be used freely may be donated, either in whole or in part, either to non-heirs or their children or to other people who have the right to the inheritance. Grants consisting of existing and certain objects cannot be withdrawn, unless the requirements of the grant are not met.

The parties who can give and receive grants are all people except those who are declared incapable by law, for example, minors and married couples during an ongoing marriage. The giver of the grant is the legal owner of the goods being donated and at the time the gift is made, he is in good health, both physically and spiritually. In addition, the grantor must meet the requirements as an adult and capable of taking legal action and owning the property or goods being donated. Basically, the grantor is any person and/or law capable of carrying out legal actions. ${ }^{9}$ The recipient of the grant is every person, both individuals and legal entities and is eligible to own the goods that are donated to him. The grantee is required to be a person who is capable of taking legal action. If he is a minor, he is represented by his guardian or submitted to the supervision of his guardian until the owner of the grant is capable of taking legal action. In Article 1667 of the Civil Code that "Grants may only be made to goods that already exist at the time the grant occurs. If the grant includes items that do not yet exist, then the grant is void only regarding items that do not yet exist.

The period of the registration process for the transfer of rights due to a grant is 5 (five) working days from the registration of the file until the submission of the

${ }^{9}$ Zainuddin Ali. 2008. Pelaksanaan Hukum Waris di Indonesia. Jakarta, Sinar Grafika, p. 76 
certificate to the applicant. However, the registration process for the transfer of rights due to a grant will take a long time if the applicant (grant recipient) does not meet the requirements specified in PMNA/KBPN Number 3 of 1997 and the provisions of Government Regulation Number 24 of 1997.

\section{Closing}

The implementation of the transfer of ownership rights to land on a grant basis in Kebumen Regency has been carried out in accordance with the provisions of the applicable laws and regulations. Whereas the transfer of land ownership rights through grants in the Regency is carried out in 2 stages, namely first, making a grant deed at the Land Deed Making Officer. Then the second stage of registration at the National Land Agency of Kebumen Regency. Article 37 paragraph (1) and Article 39 of Government Regulation No. 24 of 1997, explains that every grant of land must be made with a PPAT deed. The implementation of land administration and land registration recorded at the Land Office must always be in accordance with the actual situation or status. The condition and status of the land parcel in question, both concerning the physical data regarding the said land parcel, as well as regarding the legal relationship concerning the said land parcel, or this juridical data, in particular the recording of changes to the previously recorded juridical data. This is related to the important role of PPAT in land registration. Barriers to making grant deeds and land registration are caused by various factors that greatly influence the determination of rights certainty and the problem of the high cost of land registration being a separate obstacle for the community, especially rural communities. To overcome obstacles, the Land Office continues to try to help the community by carrying out various activities such as: counseling/socialization about the benefits of Land Registration, carrying out land registration with PRONA and PRODA in order to raise public awareness and weak economic groups can obtain legal certainty over land rights. Because it is the responsibility of the Land Office.

\section{References}

Journals:

[1] A Chuasanga, Ong Argo Victoria. (2019). Legal Principles Under Criminal Law in Indonesia Dan Thailand, Jurnal Daulat Hukum, Vol 2, No 1 (2019) http://jurnal.unissula.ac.id/index.php/RH/article/view/4218

[2] Alam, Bahrul., \& Khisni, Akhmad. (2020). Legal Protection of Holders of Land Loss Data In The City Land Office of Kendari. JURNAL AKTA: Vol.7, No. 2, 159-164. Retrieved from http://jurnal.unissula.ac.id/index.php/akta/article/view/7963 
[3] Arrohim, Mohammad B., \& Wahyuningsih, Sri Endah. (2020). Analysis of Judicial Application of Criminal Penalty Against Notary / Land Deed Officials Conducting Making Crime of the Fake Authentic Deed in State Court of Semarang. JURNAL AKTA: Vol.7, No. 2, 183-188. Retrieved from http://jurnal.unissula.ac.id/index.php/akta/article/view/7891

[4] Deen, Thaufiq., Ong Argo Victoria \& Sumain. (2018). Public Notary Services In Malaysia. JURNAL AKTA: Vol. 5, No. 4, 1017-1026. Retrieved from http://jurnal.unissula.ac.id/index.php/akta/article/view/4135

[5] Ong Argo Victoria, (2018) Waqf Al-Nuqūd In Indonesia (In Law Perspective), Jurnal Pembaharuan Hukum Vol 5, No 1 Universitas Sultan Agung, http://jurnal.unissula.ac.id/index.php/PH/article/view/2999

[6] Sukarmi, S., \& Victoria, A. (2018). Cash Waqf in Sustaining Of Indonesian Society "In Legal \&amp; Economic Perspective". AL-ITQAN: JOURNAL OF ISLAMIC SCIENCES AND COMPARATIVE STUDIES, 2(1), 83-97. https://doi.org/10.31436/al-itqan.v2i1.43

Books:

[1] A.P. Parlindungan. 2009. Pendaftaran Tanah di Indonesia. Bandung, Penerbit Mandar Maju

[2] Abdul Kadir Muhammad, 1994, Hukum Harta Kekayaan, Cetakan I, Citra Aditya Bakti: Bandung

[3] Abdullah bin Abdurrahman Alu Bassam, 2002, Syarah Hadis Pilihan Bukhari Muslim, PT Darul Falah: Bekasi

[4] Achmad Ali, 2002, Menguak Tabir Hukum, Ghalia Indonesia: Bogor

[5] Achmad Ali, 2009, Menguak Teori (Legal Theory) dan Teori Peradilan (Judicialprudence) termasuk Interprestasi Undang-Undang (Legisprudence), Predana Media Group: Jakarta

[6] Adrian Sutedi. 2013. Peralihan Hak Atas Tanah dan Pendaftarannya. Jakarta: Sinar Grafika

[7] Ali Achmad Chomzah, 2004, Hukum Agraria (Pertanahan Indonesia), Jilid 2, Prestasi Pustaka Publisher: Jakarta

[8] Al-Quran Surat An-Nisa ayat 58, Yayasan Penyelenggara Penerjemah dan Penafsir Al-Qur'an, Al-Qur'an dan Terjemahnya, 2012, Kementerian Agama RI: Jakarta

[9] Anisitus Amanat. 2000. Membagi Warisan Berdasarkan Pasal-pasal Hukum Perdata BW: Jakarta, PT. Raja Grafindo Persada

[10] Asri Arinda, Pelaksanaan Peralihan Hak Milik Atas Tanah Melalui Hibah Untuk Anak Di Bawah Umur: Jurnal Repertorium Vol. III No. 22016

[11] Bachtiar Effendie. 1993. Pendaftaran Tanah di Indonesia, dan Peraturan-Peraturan Pelaksanaannya. Bandung: Alumni

[12] Boedi Harsono, 1994, Hukum Agraria Indonesia, Sejarah Pembentukan Undang-Undang Pokok Agraria. Isi dan Pelaksaannya, Jilid I Hukum Tanah Nasional, Djambatan: Jakarta 
[13] Boedi Harsono. 1995. Hukum Agraria Indonesia Sejarah PembentukkanUUPA, Isi dan Pelaksanaanya, Jakarta: Djambatan

[14] Boedi Harsono. 1995. Hukum Agraria Indonesia Sejarah PembentukkanUUPA, Isi dan Pelaksanaanya. Jakarta: Djambatan

[15] Chainur Arrasjid, 2008, Dasar-Dasar Ilmu Hukum, Sinar Grafika: Jakarta

[16] Chairuman Pasaribu dan Suhrawadi K Lubis, 1996, Hukum Perjanjian Dalam Islam, Cetakan Kedua, Sinar Grafika: Jakarta

[17] Departemen Pendidikan dan Kebudayaan, 2001, Kamus Besar Bahasa Indonesia, Balai Pustaka: Jakarta

[18] Effendi Perangin, 1990, Mencegah Sengketa Tanah, cetakan ke-2, Rajawali: Jakarta

Effendi Perangin. 1990. Mencegah Sengketa

Tanah. Cetakan Kedua.Jakarta: Rajawali

[20] Effendi Perangin. 1994, Hukum Agraria Indonesia, Suatu Telaah Dari Sudut Pandang Praktisi Hukum, Raja Grafindo: Jakarta

[21] Eman Suparman. 2011. Hukum Waris Indonesia dalam Perspektif Islam, Adat, dan BW. Bandung: PT. Refika Aditama

[22] Eman Suparman. 2011. Hukum Waris Indonesia dalam Perspektif Islam, Adat, dan BW. Bandung, PT. Refika Aditama

[23] H. Hadari Nawawi, 2000, Penelitian Terapan, Gajah Mada University Press: Yogyakarta

[24] H. Salim HS, H. Abdulah, dan Wiwiek Wahyuningsih, 2014, Perancangan Kontrak dan Memorandum of Understanding (MoU), Sinar Grafika: Jakarta

[25] Imam Gunawan, 2015, Metode Penelitian Kualitatif: Teori dan Praktek, Jakarta: PT Bumi Aksara

[26] M.Solly Lubis, 2007, Filsafat Ilmu Dan Penelitian, Bandung: Mandar Maju

[27] Madjid Khadduri, 1999, Teologi Keadilan (Perspektif Islam), Risalah Gusti: Surabaya

[28] Moleong, Lexy J.,2007, Metodologi Penelitian Kualitatif, Penerbit PT Remaja Rosdakary, Offset: Bandung.

[29] Notohamidjojo, 2011, Soal-Soal Pokok Filsafat Hukum, Griya Media: Salatiga

[30] Novitasari, 2016, Tinjauan Yuridis Pelaksanaan Peralihan Hak Milik Atas Tanah Melalui Hibah di Kabupaten Karanganyar: Skripsi

[31] Paulus Hadisoeprapto,dkk, 2009, Pedoman Penulisan Usulan Penelitian dan Tesis, UNDIP: Semarang

[32] Peter Mahmud Marzuki, 2008, Pengantar Ilmu Hukum, Kencana Pranada Media Group: Jakarta

[33] Peter Mahmud Marzuki, 2008, Pengantarllmu Hukum, Kencana: Jakarta 
[34] Philipus M. Hadjon, 1987, Perlindungan Hukum Bagi Rakyat Indonesia, Bina Ilmu: Surabaya

[35] R. Soeroso, 2009, Pengantar Ilmu Hukum, Sinar Grafika: Jakarta

[36] R. Subekti, 1994, Pokok-pokok Hukum Perdata, Internus: Bandung

[37] Rusdi Malik, 2000, Penemu Agama Dalam Hukum, Trisakti: Jakarta

[38] Satjipto Raharjo, 2000, Ilmu Hukum, PT.Citra Aditya Bakti: Bandung

[39] Sayyid Quthb, 1999, Keadilan Sosial dalam Islam, Pustaka Setia: Bandung

[40] Soedikno Mertokusumo, 1988, Hukum dan Pokok Agraria, Karunika-Universitas Terbuka, Jakarta

[41] Soeryono Soekanto, 1998, Pengantar Penelitian Hukum , UI Press, cetakan ke-3: Jakarta

[42] Sudikno Mertokusumo, 2009, Penemuan Hukum, Citra Aditya Bakti: Bandung

[43] Supriadi, 2010, Hukum Agraria, Cetakan Keempat, Sinar Grafika: Jakarta

[44] Urip Santosa. 2012. Hukum Agraria. Jakarta: Kencana Prenada Media Group

[45] Yudha Bhakti Ardiwisastra, 2012, Penafsiran dan Konstruksi Hukum, PT. Alumni: Bandung

[46] Zainuddin Ali. 2008. Pelaksanaan Hukum Waris di Indonesia. Jakarta: Sinar Grafika

Regulations:

[1] Act No. 24 of 2015 concerning the Land Agency.

[2] Act No. 35 of 2014 concerning Child Protection Amendments to Act No. 23 of 2002.

[3] Act No. 5 of 1960 concerning Basic Regulations on Agrarian Principles (UUPA).

[4] Civil Code (KUHPerdata) on Grants.

[5] Constitution of the Republic of Indonesia 1945

[6] Government Regulation Number 18 of 2021 regarding Land Registration.

[7] Government Regulation of the Republic of Indonesia Number 24 of 2016 concerning Amendments to Government Regulation Number 37 of 1998 concerning Regulation of PPAT Positions. 